\title{
The Maritime Silk Road's potential effects on outer island development: The Natuna Islands, Indonesia
}

\author{
Hertria Putri \\ Doctoral Program in Regional and City Planning, Institut Teknologi Bandung, Indonesia \\ hertria.maharani@gmail.com (corresponding author)
}

\section{Wilmar Salim \\ Department of Regional and City Planning, Institut Teknologi Bandung, Indonesia wsalim@pl.itb.ac.id}

\begin{abstract}
The development of peripheral or outer islands is not widely discussed in the literature on national economic development. As peripheral and remote areas, outer islands and archipelagos are often ignored because they are deemed unimportant to a country's economic growth. China's Belt and Road Initiative (BRI), which aims to open channels of trade and connectivity, may influence island development and alter relationships between outer islands and their associated mainlands. The Natuna Islands are a remote outer archipelago of Indonesia's Riau Islands Province but now find themselves on the path of China's 21stCentury Maritime Silk Road (MSR), a key element of the BRI. This paper uses outcome mapping to explore how the MSR may have positive and negative impacts on Natuna's island community. Improved communication, infrastructure, and barrier-free trade will enhance the archipelago's territorial capital, yet it is important that the island community approaches these developments with care. Community participation and community capacity building are needed to prevent negative developmental trajectories that cause social and environmental harm.
\end{abstract}

Keywords: Belt and Road Initiative (BRI), development, Indonesia, Natuna Islands, outer islands, $21^{\text {st }}$-Century Maritime Silk Road (MSR)

https://doi.org/10.24043/isj.136 • Received January 2020, accepted October 2020

(C) 2020-Institute of Island Studies, University of Prince Edward Island, Canada.

\section{Introduction}

Peripheral or outer islands are often neglected in the study of national economic development. Located far from economic and political centers, outer islands struggle to become sites for growth. Such islands may also confront limitations related to their island status, in terms of limited resources, land area, and availability of both tangible and intangible capital (Ma \& Wu, 2019). There is a degree of circularity in these processes, as the developmental potentials of outer islands characterized by a combination of remoteness, smallness, oceanic environment, and geographical proximity to other countries (Kakazu, 2011; Anderson, 2007) are especially likely to be neglected and overlooked, with the result that outer islands always remain on the periphery. 
It is nevertheless necessary to move beyond the national core when seeking to understand regional development. Geopolitical perspectives in particular highlight the importance of peripheral and border zones for shaping state sovereignty, serving as gateways into the wider national economy, and functioning as strategic meeting points between states (Pugalis \& Gray, 2016; Mountz, 2011; Barca, 2009). Geopolitical perspectives attend to efforts to exert national or other forms of control over a region's space, resources, routes, population, and industries (Blouet, 2001). Studies of regional development cannot focus on a place as an isolated entity at a subnational, national, or multinational scale but must instead consider how these places relate to other places outside the national borders (Hettne \& Söderbaum, 1998).

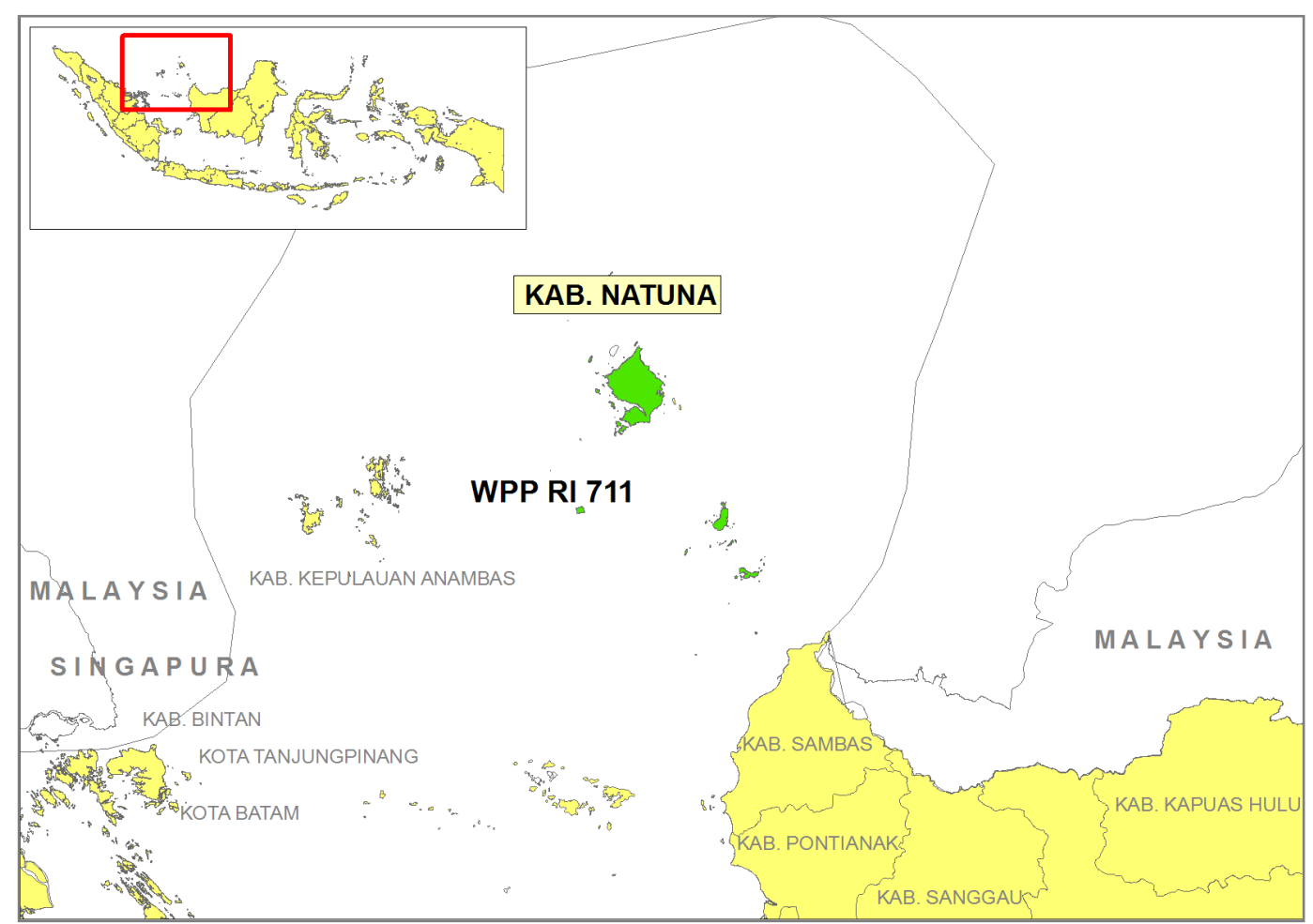

Figure 1. Natuna Islands, Riau Islands Province, Indonesia. Source: Ministry of Marine and Fisheries (2016).

This article uses the case of the Natuna Islands, Indonesia to consider how 'outer islands' are drawn into change processes driven by the national center as well as how projects like China's $21^{\text {st }}$ Century Maritime Silk Road have the potential to positively and negatively alter local developmental trajectories..

The $21^{\text {st }}$-Century Maritime Silk Road (MSR) project, which is part of the Chinese government's Belt and Road Initiative (BRI), seeks to build connections between countries and regions as a means of economic expansion and acceleration. Locations located along the MSR's strategic path have an opportunity to develop themselves as a result. The Natuna Islands (Figure 1) are an outer island region of Indonesia, peripheral to the national core, yet they also lie along the MSR route and thus play an important role in the context of world trade. This has implications for the archipelago's increasingly marginalized communities, which both have special developmental needs and have developed cultural strategies for responding to new influences on account of their separation from other territories (Lattas, 
2007). It is unclear at present, however, whether appropriate action is being taken to address local needs within either the national or MSR development models.

This article argues that increased connectivity and significant new inflows of capital can potentially have both positive and negative impacts on island communities. In order to build this argument, this article will be divided into four parts. The first concerns the BRI and MSR vision to understand the set of macro-level ideas, goals, principles and steps. The second is Natuna's territorial and geopolitical context. The third is the potential impact of the MSR on the Natuna Islands, analyzing the potential impacts that will occur on the island. Fourth is a discussion of how participation of the island community could minimize the negative impacts.

\section{Methodology}

This paper employs a qualitative approach in order to achieve complex textual descriptions and reveal their implications (Lune \& Berg, 2017). Instead of assessing potential impacts of the MSR on outer islands in terms of quantitative data, this paper seeks an improved understanding of social relations in the outer islands context. The analysis of potential impacts will be guided by the outcome mapping framework, a methodology for planning and assessing development programs oriented toward social change and transformation (Earl, Carden, \& Smutylo, 2001). Outcome mapping provides a set of tools for designing and gathering information concerning results, which are defined as a behavioral change resulting from the change process. The outcome mapping methodology has been selected in order to ascertain which social changes may occur due to the MSR, which is regarded as a complex process and a program that cannot be considered in isolation from the interactions of the various actors which are critical to its implementation (for example, donors, partner organizations, governments, communities, community organizations, and groups). This approach also pays appropriate attention to social, political, cultural, economic, historical, and environmental factors (Dyer, 2012).

This article uses outcome mapping to assess the potential impacts of MSR implementation in the Natuna Islands as it can provide a systematic methodology for assessing potential impacts and innovations. The Natuna Islands were chosen because they are among the archipelagos traversed by the MSR and because they are a peripheral outer island area of geostrategic importance for the maintenance of Indonesia's sovereignty. Out of three levels of outcome mapping, the 'intentional design' level is used, which focuses on the planning of program strategies. The program strategy will be right on the target when it can answer questions concerning: Why? (To which vision does the program seek to contribute?), Who? (Who are the program partners?), What? (What changes are being sought?), and How? (How can the program contribute to the change process?).

\section{Belt Road Initiative and Maritime Silk Road: Between vision and implementation}

The Belt Road Initiative (BRI) aligns with the geopolitical perspective that sees geography as playing an important role in regional development (Fettweis, 2015), which is part of the wider process of globalization (Zhiding \& Dadao, 2016). Some countries have responded positively to increasingly borderless forms of regional development (Agnew, 2015). In 2013, 
the Chinese government launched the project to revitalize the ancient Silk Road within the BRI framework as a means of promoting development and mutual prosperity between China and Central Asian countries. This program aims to develop terrestrial, marine, and air infrastructure on a large scale, thereby improving and creating trade and economic connections between countries in Asia, East Africa, the Mediterranean, and the Pacific. It also aims to offer an outlet for China's excess industrial capacity in cement, steel, and aluminum production; to enhance the intermediary functions of Chinese banks in China; and to expand the search for new markets (Ferdinand, 2016; Eisenman \& Stewart, 2017).

More than 60 countries, equalling 40\% of global GDP and $65 \%$ of the world's population, have joined in BRI projects. Such a strategy for transcending jurisdictional boundaries can alter regional center-periphery dynamics (Fulton, 2016). Infrastructure development within the BRI as a whole is oriented toward enhancing connectivity (see Figure 2). Within the MSR, sea lanes will move from the South China Sea to the Indian Ocean, East Africa, the Red Sea, and the Mediterranean Sea.

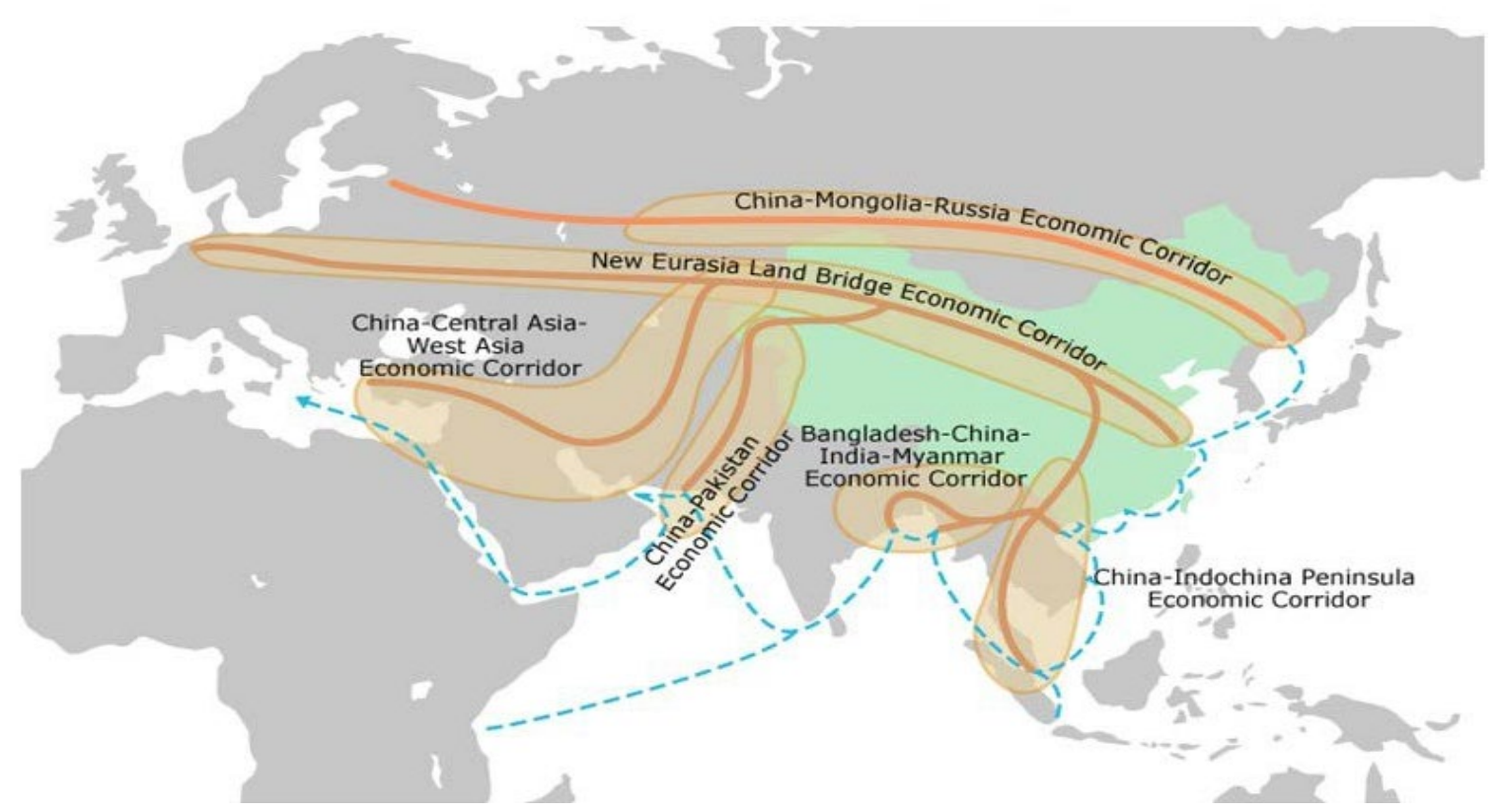

Figure 2. Roadmap for the Belt and Road initiative. Source: http://china-traderesearch.hktdc.com

The BRI project is built upon the underlying principles of policy coordination, facility and infrastructure connectivity, barrier-free trade, integrated financial systems, and strengthening inter-community bonds (Fulton, 2016). These principles have several implications (Table 1). 
Table 1. Principles and implications of the Belt and Road Initiative. Source: Adapted from Fulton (2016) and Du (2016).

\begin{tabular}{|l|l|}
\hline Principles & \multicolumn{1}{|l|}{ Implications } \\
\hline Policy coordination & $\begin{array}{l}\text { - China and partner countries must make agreements, not just } \\
\text { initiatives } \\
\text { - Assessment of facilitation agreement through multilateral } \\
\text { organizations. }\end{array}$ \\
\hline $\begin{array}{l}\text { Facilities and } \\
\text { infrastructure } \\
\text { connectivity }\end{array}$ & $\begin{array}{l}\text { - Clear regulations regarding finance } \\
\text { - Identification of infrastructure network requirements }\end{array}$ \\
\hline Barrier-free trade & $\begin{array}{l}\text { - Increasing market competition and the need for local } \\
\text { business players to compete globally. }\end{array}$ \\
\hline Integrated finance & $\begin{array}{l}\text { - Increased globalization of investments that seek higher } \\
\text { returns and opportunities to diversify international risk, } \\
\text { necessitating in-depth observations regarding the financial } \\
\text { process so that no party is harmed. }\end{array}$ \\
\hline $\begin{array}{l}\text { Strengthening inter- } \\
\text { community bonds }\end{array}$ & $\begin{array}{l}\text { Each country must understand the needs of the people and } \\
\text { improve the quality of community participation. }\end{array}$ \\
\hline
\end{tabular}

Synergy between the five principles must be achieved. The BRI must consider not just infrastructure but also how infrastructure development affects social transformation processes. China and other participating countries must take concrete action: strong political will is required to bridge the gap between ideas and implementation. Key stakeholders include government ministries of foreign affairs, national development planning agencies, regional and local governments, and other relevant government bodies.

The large number of stakeholders can cause collaboration to fail. This is due to the absence of effective ownership and the fact that the main beneficiaries often have little voice and power (Gibson et al, 2005). This creates a mismatch between what does occur and what should occur. Many aid providers and capital owners fail to communicate effectively with potential recipients of capital. Absence of communication can lead to program failures such as misuse of funds by the local leaders, mismatch between provision of technology and people's purchasing power, environmental damage, and mismatch between provision of employment opportunities and conditions in the community (Turner \& Müller, 2003). The necessity of engaging in intense and effective communication becomes especially challenging in the case of outer island development. Outer islands traversed by the MSR may be spatially isolated places that experience abrupt changes in access, connectivity, and investment.

It is too early to predict the MSR's success or failure at improving the welfare of outer islands. Deeper theoretical and empirical research must be conducted in order to anticipate the MSR's impact on small islands in East Asia, Southeast Asia, South Asia, the Indian Ocean, and East Africa. The positive and negative impacts of increased connectivity on outer islands are of vital importance both for the island communities themselves and for the countries of which these islands form a part. 


\section{Territorial context: Characteristics and geopolitics of outer island development}

Outer islands play a special role in a country's geopolitics. Their development is highly dependent on their country's geopolitical architecture, namely the direction and steps taken by the state to access, arbitrate, manage, and regulate the intersection of territory and movement and to establish boundaries between inside and outside, domestic and international (Dodds, 2007). Outer islands may feature in national geopolitics in a number of ways, for example as sites for military bases or simply as places that attract international political attention. Some outer islands are so-called 'contested' or 'disputed' islands, over which various states advance claims of sovereignty (Baldacchino, 2017; Ratter, 2017).

Natuna is an archipelago consisting of 154 islands, of which 27 are inhabited, scattered across a wide expanse of ocean. The Natuna Islands are not only located along the MSR but are also contested by or of geopolitical interest to a number of countries participating in the MSR. The Natuna Islands possess strategic importance due to their location: they are Indonesian territory bordering Vietnam and Cambodia to the north, the Indonesian provinces of South Sumatra and Jambi to the south; Singapore, Malaysia, and the remainder of the Riau Archipelago to the west; and East Malaysia and West Kalimantan to the east. Natuna is on the international shipping lines of Hong Kong, Japan, South Korea, and Taiwan. Beyond its locational resources, Natuna also possesses rich oil, gas, and fishery resources. The gas reserves in Natuna waters, discovered in 1973, are predicted to amount to around 222 trillion standard cubic feet (TCF). Natuna waters can produce 500 thousand tons of fish per year (Supriyanto, 2015), including fish from Indonesia's North Natuna Sea Exclusive Economic Zone. In 2015, 48,968.85 tons of fish were landed in Natuna (Natuna Fisheries Service, 2017).

Outer islands' economic developmental potential is influenced by their maritime environment, with the sea providing some resources and limiting others. It is, however, important not to overlook the crucial influence of the cultural traditions and customs of local island populations and the physical environments of the islands themselves ( $\mathrm{Ma} \& \mathrm{Wu}, 2019$; Hatfield \& Hong, 2019). In archipelagic countries consisting of a great many small islands, the development of small and outer islands may not be prioritized: distance from activities occurring at the center of power mean that the importance of developing outer islands is frequently overlooked or frequently seen to be overlooked (Kirch, 1986).

Outer islands located in border regions are characterized by special kinds of relationships with the core or central regions of their own countries as well as with neighbouring countries (Anderson, 2007). In border areas, interactions with other national communities are unavoidable and have the potential to cause conflict if they are ignored by central government authorities. A place that is an 'outer island' from the perspective of its central government may be a nearby island from the perspective of another country. Cross-border interactions raise the potential for cultural and economic exchange as well as the building of trust among various island and mainland communities (Richardson, 2016). The Natuna Islands host intense cross-border interaction with Singapore and Malaysia in particular, and many Natuna Islands businesses are more dependent on links with Singaporean businesses than with other businesses located in Natuna. For example, fish caught in Natuna waters tend to be sent to Singapore, with prices determined by the buyer and the fishers themselves having relatively little economic power. For Natuna, then, Singapore serves the role that domestic large island hinterlands do for small island communities elsewhere in Indonesia (Nurdin \& Grydehøj, 2014). 
Both these characteristics distance outer islands from their respective centers, often producing economic inequality and marginalization. State emphasis on neoclassical approaches to national development, which focus on national-level economic growth and commodity competitiveness, can further pull attention away from islands on the periphery. Government development programs emphasize macroeconomic growth and often ignore large gaps between those locations favored by investors (based on location theory) and peripheral locations, thereby reducing the range of natural resources in the area that end up being demanded by the core region (Busega \& Postoiu, 2015).

Residents of outer islands often feel 'left behind' due to economic and social marginalization (Haug, Rössler, \& Grumblies, 2016), and the islands are considered as peripheral to the center of activity (Kuwahara, 2012). Outer islands struggle to catch up with the center because the center's interest in the periphery is largely restricted to those resources it can extract from it (Dunn, Chase, \& Hall, 1997). Peripheral areas also often lack political and economic power as well as the capacity to improve community welfare. The emergence of zero-sum, winner and loser power relations between central and peripheral areas raises the potential for territorial disintegration, especially in border zones between countries (Weissenbacher, 2017).

The Natuna Islands have undergone a centrally driven development process separate from the establishment of the so-called SIJORI Cross-Border Region or SIJORI Growth Triangle, which encouraged integrated development among Singapore, Johor, and Riau (including today's Riau Islands Province, of which the Natuna Islands are a part) (Hutchinson \& Chong, 2016). As a result, the Natuna Islands experience many negative backwash effects of economic activities in the both the nearby SIJORI center and the more distant national center: Natuna's human resources remain relatively undeveloped, there is little local investment, emigration pulls workers and skills away from the islands, natural resources (gas, oil, and fishery products) are extracted for the benefit of other regions, and local businesses are stuck in the role of price takers rather than price makers due to insufficient power and access to information (Putri \& Salim, 2019). Such problems are present in many other peripheral island communities (Clark, 2009). Natuna's peripherality also raises the price of local goods and services and limits the availability of electricity (Siregar, 2009). All this contributes to Natuna's population being dependent on small-scale fishing livelihoods. The islands' social structure has been developing at a slow rate because there it is little increase in welfare (including in education and health) over time.

Thanks to the emergence of the MSR, Natuna's development is now shifting from being primarily of peripheral economic importance to the center to being of significant geopolitical importance. These islands' peripherality from the center has occasioned economic hardship, but their position in a maritime border zone and along an emerging transnational and interregional trade route hold out great potential. Government bodies and planning authorities must seek to turn these island disadvantages into advantages (Kakazu, 2011). 


\section{Potential impacts of the $21^{\text {st }}$-Century Maritime Silk Road on Natuna's development as an outer island region}

\section{Policy coordination}

Potential impacts of the MSR may include enhancements to tangible aspects of territorial capital, as defined by Camagni and Capello (2013, p. 1387), i.e. "the set of localized assetsnatural, human, artificial, organizational, relational and cognitive-that constitute the competitive potential of a given territory." However, this must be accompanied by policies that encourage the development of more intangible elements of territorial capital as well.

All countries involved in the cross-border region around Natuna (most significantly, Indonesia, Singapore, Malaysia, Vietnam, and China) need to effectively coordinate their development programs, including the coordination of existing investment schemes in Riau Islands Province. All countries should also coordinate on regulatory issues to ensure legal compatibility. The lack of attention to the Natuna Islands and a general lack of political will to grapple with regulatory complexities in the earlier development of the SIJORI CrossBorder Region hindered economic integration and pursuit of shared objectives. Cooperative development through the SIJORI project is often seen as failing, with Singaporean firms reaping the lion's share of cross-border benefits (Diez, Breul, \& Moneke, 2019). SIJORI's failure to meet its massive expectations demonstrate the price of inaction and insufficient cooperation by policymakers and economic actors (Sjarif, 2000).

Intensive communication can diffuse tensions of the kind that have in the past arisen between the governments of Indonesia and China. Chinese investment in Riau Islands Province has proved controversial. This is especially so in the wake of maritime dispute, diplomatic conflict, and naval confrontation in 2016-2017 related to Natuna waters (Setijadi, 2018): the governments of China and Vietnam unilaterally claimed the North Natuna Sea as their traditional fishing grounds (Riska, 2017). Policy coordination will benefit all parties in the sense that good communication is key to resolving any kind of dispute. However, the coordination process ideally involve all participating countries possessing a clear understanding of Natuna's strategic positioning and assets in the international arena. Besides holding gas resources, Natuna territory is widely utilized by the fishing fleets of not just Indonesia but also China, Vietnam, and Thailand (Supriyanto, 2015). Much of this fishing is illegal, unreported, and unregulated, despite these waters being part of Indonesia's exclusive economic zone, and much of the fisheries catch ends up in markets outside Indonesia. Getting to grips with destructive fishing practices requires more than just national legislation; it requires collaborative regional efforts.

\section{Connectivity based on facilities and infrastructure development}

Massive and rapid development has the potential to disrupt island societies and environments. The creation of hard infrastructure, ports, or even just shipping lanes can cause direct and indirect environmental damage, for example when waste is expelled from passing ships; when improved facilities and technologies lead to overexploitation of fishery resources; and when local consumption patterns change due to the introduction of new products, livelihoods, and lifestyles.

Enhanced accessibility also encourages both immigration and emigration. Islands have long been characterized by complex patterns of emigration and immigration, which are influenced by the relative availability of island and mainland employment and education, the 
relative ease and expense of transport options, and many other factors (Grydehøj \& Casagrande, 2020; Cooke \& Petersen, 2019; Gamlen, Murray, \& Overton, 2017; Connell \& King, 1999). Too much emigration may threaten the sustainability of island communities, yet emigration and associated flows of remittances have long been recognized as a key element of many island economies (Bertram \& Watters, 1985). Meanwhile, immigration can be a source of much-needed skills, yet too much immigration can prompt tensions in island communities. MSR projects are often explicitly planned as being designed, run, constructed, and operated using Chinese technology, materials and labor (Ellis, 2017), risking social conflict. Large inflows of immigrants - whether skilled, highly paid workers; unskilled, inexpensive labor; refugees; family or lifestyle immigrants; or other kinds of migrants - are frequent sources of discord and inequality in island communities (e.g. Grydehøj, 2020, 2011; Otto, Nimführ, \& Bieler, 2019; Baldacchino, 2012).

Of course, conflict between longstanding island residents and immigrant groups is not limited to international migrants: tensions have risen in the Natuna Islands between local fishermen and immigrant fishermen from elsewhere in Indonesia, such as Java's Tegal Regency. With their large boats and more modern fishing gear, the immigrant fishermen have succeeded in outcompeting local fishermen, who use traditional spears and fishing rods. This has led to income and revenue disparities as well as lack of transfer of knowledge and resources. Bearing such issues in mind, the MSR offers opportunities for both encouraging and managing the movement of people and resources, not just between countries but also within countries.

The channelling of large sums of money into helping make island communities better connected can furthermore risk eroding local values. For example, externally funded infrastructure construction can come to serve as its own rationale, resulting in 'compensatory destruction' (Lee, Huang, \& Grydehøj, 2020), and the creation of new connective infrastructures can greatly alter the ways in which island societies and economies function (Zhang \& Grydehøj, 2020). It is thus important to always ensure that development projects are genuinely needed by local communities and genuinely enhance community services. It is also important that the creation of new connections to and from islands is balanced by regulatory coordination and supervision in order to avoid the harming of island communities and wider national interests.

\section{Barrier-free trade}

The free trade promoted by the Chinese government is a double-edged sword, especially for countries and territories that are not yet competitive on the international market. In such cases, free trade may erode parts of the economy that are not ready to produce high valueadded goods, causing countries and places to primarily become suppliers of raw materials and/or consumers of goods produced elsewhere. As exporting and importing become easier, environmental and resource sustainability are affected. The Natuna Islands, for example, rely economically on the extraction and export of natural resources as raw materials: increased international access and demand may both place environmental sustainability at risk and make the islands increasingly dependent on low value added exports. The lowering of legal and practical barriers to trade could flood Natuna's markets with cheap imports, thereby demolishing the kind of natural protections that peripheral island geographies can provide to local businesses. 


\section{Integrated finance}

The granting of aid and loans must be examined for effectiveness. Small Island Developing States (SIDS) are particularly good at attracting aid and investment (Connell, 2018), in part due to the manner in which island spatiality helps render the impact of investment exceptionally conspicuous and thus of value to donors and lenders (Grydehøj \& Kelman, 2020). As a result, however, SIDS tend to hold disproportionate amounts of debt relative to their size and development status (King \& Tenant, 2014). Although large volumes of spending in limited areas can help produce big and visible results in island communities (Grydehøj \& Kelman, 2017), Natuna-like many outer island territories — is at such a low developmental stage as to require massive investment from government funders that are prepared to bear the risk or even certainty of no returns. Crucially, investors - whether government, corporate, or NGO-must design investments in such a manner as to ensure that the benefits are not disproportionately being accrued by non-island residents, particularly in situations in which the islanders themselves end up being saddled with debt.

\section{Strengthening inter-community bonds}

The strengthening of inter-community bonds is believed to positively impact regional development. The BRI's scope encompasses investment in not just hard infrastructure but also soft infrastructure such as trade agreements, tourism, and community relations such as education and cultural exchange (Hillman, 2018). The BRI's principles that prioritize this dialogue should explicitly encompass island communities. Strengthening bonds between island communities can help ensure the participation of communities in joint decision-making processes as well as create 'island networking', as seen in the Taiwan-Okinawa-Kyushu Economic Zone and the Okinawa-Taiwan Special Free Trade Zone (Kakazu, 2011). The existence of inter-island networks can facilitate the formation of new cores and the development of new archipelagos (Fernandes, 2017).

Strengthened bonds and more relations are not inherently good or bad. It is possible that closer links between communities will contribute to some of the negative processes considered above. If properly utilized though, the MSR has the potential to alter centerperiphery relations and strengthen outer islands relative to their national centers. The improved outer island connectivity encourages a shift from thinking of places as isolated islands' to thinking of them in more nuanced archipelagic terms (Figuero, 2020; Pugh, 2016; Xie, Zhu, \& Grydehøj, 2020). Such changes in center-periphery relations occur in part because processes such as the MSR invest islands with new territorial capital. This territorial capital consists of a set of localized assets that gain value when placed in new cross-border, transnational, and interregional contexts (Camagni, 2009). By making use of their territorial capital, island communities can seek to improve local economy and welfare, ultimately gaining comparative advantages that help boost these communities' long-term opportunities (van der Ploeg, 2008; Ventura et al., 2008; Berti, 2011) and encourage more balanced regional development (Bynens \& Van der Lecq, 2005).

\section{Participation of island communities in outer island development}

Bearing in mind the potential positive and negative impacts of enhanced connectivity, more open trade, increased incoming investment, and deepened inter-community bonding as a 
result of the MSR, it is vital that island communities take an active role in relation to the MSR project so that they do not merely become spectators to the change process. This discussion on the role of island communities arises from the MSR's potential impacts, which affect the lives of islanders and their environment. As discussed earlier, the impact of the MSR will make the island region, as an openly accessible area, the site of migration. The newcomers might threaten the island's cultural values. The islands will also experience environmental changes and possibly environmental damage. But opening up connectivity is also an opportunity for the island community to gain political access, connect with other areas, and even change the core-periphery relationship (Royle, 2001).

With various impacts that may arise, the island community is an important actor in any decision-making related to island regulation. The absence of the island community will cause the loss of local cultural values, damage to environmental conditions, and conflict by various external factors. Without understanding the importance of establishing people-to-people bonds, there will be marginalization of island communities that have long been regarded as 'incapable' by metropolitan actors. Island residents are typically best placed to understand the needs and conditions of island communities (Balai Besar Riset Sosial Ekonomi Kelautan dan Perikanan, 2017; Graci \& Dodds, 2010; Haynes, Barclay, \& Pidgeon, 2008). The physical boundaries, geographical isolation and compact sociopolitical universe of islands contribute to the social construction of an islander identity or community as different or unique and separate from communities found elsewhere (Grydehøj, Nadarajah, \& Markussen, 2020; Anderson, 2003). Even researchers who are equipped with theoretical knowledge might misinterpret or skew the needs of island communities (Baldacchino, 2008).

The tangible assets of territorial capital must be supported by intangible assets, such as relational and social capital, which are often key to successful development projects, including infrastructure development (Perucca, 2013). This applies to islands in particular, given that they are often associated with distinct cultures and ways of life as well as with powerful social capital (Baldacchino, 2005). The island community itself must be the driving force for island development.

Island communities should participate in every step of the MSR implementation process. Central or provincial government stewardship is no longer enough, especially since the inter-island and other networks created by the MSR provide the opportunity for island communities to draw upon an expanded array of capacities. In our outcome mapping of the MSR's key principles (policy coordination, facilities and infrastructure connectivity, barrierfree trade, integrated finance, and strengthening inter-community bonds), we have found that all principles potentially result in a mix of positive and negative outcomes. Perhaps particularly problematically, the very fact that the such principles are being pursued by the MSR, which is structured as a set of state-to-state (largely bilateral) agreements, means that the resultant developments are unlikely to have been initiated by outer island communities themselves. It is possible that positive social transformation will result from MSR-driven change processes, but strong participation from island communities is at present simply a potential aspect ofrather than a necessary component of - these processes. Decision-making processes should empower residents in their own development through the ability to express their concerns and desires (Ying \& Xhou, 2007).

When it comes to policy coordination relevant to outer islands, outer island communities should be consulted as to what types of collaboration are possible and desirable. In terms of infrastructure development, it is the island community that is best placed to 
determine the needs of islanders, especially given the tendency for the mainland and the metropole to conceive of islands in certain essentialized ways (Chandler \& Pugh, 2020; Kelman, 2020). Outside decision-makers may not understand the complex set of factors that determine whether, for example, construction of a new harbour, bridge, or industrial facility will have net positive or negative effects on the local community. In terms of barrier-free trade, it is likewise important for island communities to be able to communicate the ways in which new trade patterns and practices affect local economies. Outer islands should be empowered to manage the terms of their engagement with MSR-driven integrated finance. Such empowerment may benefit from advice and technical assistance from central or provincial government authorities, but care must be taken to ensure that it is not simply assumed that the financial interests of the center are the same as those of the periphery. If outer island communities are to become more economically robust and self-sustaining, it is necessary that inward investments are congruent with islander interests.

For small island communities, participation in policy-making can be crucial to sustainable island development (Kelman et al., 2011). Failure to involve island communities may result in these communities being harmed. When island communities do not participate, the lack of knowledge and attention concerning island needs and circumstances risks being filled by external stakeholders that compete to make their own knowledge, rationality, and interests central to the decision-making process (Dobrucka \& Simonova, 2017). In the case of Natuna, development is often carried out by actors in the national center, with little regard for the island community's existing social relations. This is in part because central decisionmakers have already concluded that the island community lacks the necessary skills or capabilities to participate in planning its own development. Such a decision-making process, however, can only ever result in mainland solutions to island problems.

In contrast, countries such as Japan and the Philippines tend to seek to encourage outer island development through the creation of a good business climate, informed and led by island entrepreneurs and local governments (Matsumura \& Miyoshi, 2018). That is, it is the island communities' own entrepreneurial skills and spirit that guide even development projects that have been initiated from the center. Because most Natuna residents (66\%; Badan Pusat Statistik, 2018) have never completed an education, the central government feels it appropriate to impose development projects on the Natuna Islands. However, lack of skills does not equate to lack of interests; a more locally sensitive island development strategy would be for the central government or other power holders to instead focus on improving the islands' skills capacity so that islanders become more capable of pursuing their own interests. By opening up the possibility of new centers and new partners, the MSR can positively disrupt some of the problematic development processes that have become matter of course in places like the Natuna Islands. Such progress requires constant attention and commitment to involving islanders in decision-making.

\section{Conclusion}

There are a number of paradoxes related to outer island development. On the one hand, outer islands and archipelagos are regarded as isolated, behind-the-times, and underdeveloped, but on the other hand, this isolation is seen as providing a kind of social, cultural, economic, and environmental stability. On the one hand, outer islands and archipelagos are seen as 
peripheral to processes occurring in the center, but on the other hand, they frequently come to function as gateways between centers and, indeed, as central spaces on the geopolitical map. Exogenous development and massive incoming investment may make islands develop more quickly but may also harm the local population's social, cultural, economic, and environmental well-being.

Island communities must become better at harnessing new connectivity in order to enhance their territorial capital. Yet rising territorial capital will only truly benefit island communities if it can be made to contribute to the island community's intangible capital. Island communities need the ability not just to adapt and react to changing conditions in their wider national, regional, and inter-regional contexts but also to influence these changes in their own interests. Governmental bodies at all levels, NGOs, and businesses can facilitate this process by helping island communities build up their capacity to define and pursue their own developmental priorities. Projects such as the MSR are, after all, dependent on the success of all involved partners and communities. The same can perhaps be said for the Republic of Indonesia itself, a vast country that has all too often prioritized needs in the centers of political and economic power over those on the periphery.

The MSR presents risks for outer islands like Natuna, but it also presents possibilities. Increased territorial capital as a result of the MSR can reorient center-periphery relations and create new sets of relations. Outer islands need no longer be merely peripheral; they can become the core of their own networks of relation.

\section{Acknowledgments}

The authors would like to thank the Research Center for Infrastructure and Regional Development, at Institut Teknologi Bandung for providing the travel grant to present the draft of this paper at the conference on Silk Road Archipelagos: Islands in the Belt and Road Initiative, Fuzhou, China in 2019 and Adam Grydehøj as well as two anonymous reviewers for providing feedback on the manuscript.

\section{References}

Agnew, J. (2015). Understanding 'geopolitics' in an era of globalization. Rev. Tamoios, São Gonçalo (RJ), 11(2). https://doi.org/10.12957/tamoios.2015.19221

Anderson, M.L. (2003). Norfolk Island: Pacific periphery. Island, 92, 47-53.

Anderson, M. (2007). The political problems of frontier regions. West European Politics, 5(4), 1-17. https://doi.org/10.1080/01402388208424381

Badan Pusat Statistik (2018). Statistik Kesejahteraan Rakyat Kabupaten Natuna 2018.

Balai Besar Riset Sosial Ekonomi Kelautan dan Perikanan (2017). Laporan Penelitian: Model Pengembangan Sentra Kelautan Perikanan Terpadu pada Pulau Terluar.

Baldacchino, G. (2017). Solution protocols to festering island disputes: 'Win-win' solutions for the Diaoyu/Senkaku Islands. Taylor \& Francis. https://doi.org/10.4324/9781315574707

Baldacchino, G. (2012). Come visit, but don't overstay: Critiquing a welcoming society. International Journal of Culture, Tourism and Hospitality Research, 6(2), 145-153. https://doi.org/10.1108/17506181211233072 
Baldacchino, (2008). Studying islands: On whose terms? Some epistemological and methodological challenges to the pursuit of island studies. Island Studies Journal, 3(1), $37-56$.

Baldacchino, G. (2005). The contribution of 'social capital' to economic growth: Lessons from island jurisdictions. The Round Table, 94(378), 31-46. https://doi.org/10.1080/00358530500033075

Bertram, I.G., \& Watters, R.F. (1985). The MIRAB economy in South Pacific microstates. Pacific Viewpoint, 26(3), 497-519. https://doi.org/10.1111/apv.263002

Berti, G. (2011) Weaving the rural web: The dynamics of rural development in Lunigiana. Quaderni Sismondi, 12(4), 1-82.

Blouet, B. (2001). Globalization and geopolitics. Reaktion.

Busega, I., \& Postoiu, C. (2015). Inter-regional disparities in the European Union. Romanian Review of Regional Studies, 11(1), 3-14.

Bynens, J., \& Van der Lecq, R. (2005). Connecting Europe to its regions: Territorial cohesion as a toolkit for an interwoven spatial development approach. Paper presented at AESOP 2005 Vienna Conference, Administration for Spatial Planning of the Ministry of Flanders.

Camagni, R. (2009). Territorial capital and regional development. In R. Capello \& P. Nijkamp (Eds.), Handbook of Regional Growth and Development Theories (pp. 118-132). Edward Elgar.

Camagni, R., \& Capello, R. (2013). Regional competitiveness and territorial capital: A conceptual approach and empirical evidence from the European Union. Regional Studies, 47(9), 1383-1402. https://doi.org/10.1080/00343404.2012.681640

Chandler, D., \& Pugh, J. (2020). Islands of relationality and resilience: The shifting stakes of the Anthropocene. Area, 52(1), 65-72. https://doi.org/10.1111/area.12459

Clark, E. (2009). Island development. International Encyclopedia of Human Geography, 607-610. https://doi.org/10.1016/B978-008044910-4.00849-X

Connell, J. (2018). Islands: Balancing development and sustainability. Environmental Conservation, 45(2), 111-124. https://doi.org/10.1017/S0376892918000036

Connell, J., \& King, R., (1999). Island migration in a changing world. In R. King \& J. Connell (Eds.), Small worlds, global lives: Islands and migration. Cassell.

Cooke, G.B., \& Petersen, B.K. (2019). A typology of the employment-education-location challenges facing rural island youth. Island Studies Journal, 14(1), 101-124. https://doi.org/10.24043/isj.81

Curtiz, T. (2011) Islands as crossroads: Sustaining cultural diversity in Small Island Developing States. UNESCO.

Diez, J.R., Breul, M., \& Moneke, J. (2019). The SIJORI Growth Triangle. Journal of Southeast Asian Economies, 36(1), 71-90. https://doi.org/10.1355/ae36-1g

Dinas Perikanan Natuna (2017). Produksi Perikanan Natuna Tahun 2015. Perikanan Natuna.

Dobrucká, L., \& Šimonová, K. (2017). Power and knowledge in planning: The role of time and scale. Proceedings: Knowledge management in the 21 $1^{\text {st }}$ Century: Resilience, creativity, cocreation (pp, 1288-1297). St. Petersburg University.

Dodds, K. (2007). Geopolitics: A very short introduction. Oxford University Press. 
Du, M (2016). China's 'One Belt, One Road' initiative: Context, focus, institutions, and implications. The Chinese Journal of Global Governance, 2, 30-43. https://doi.org/10.1163/23525207-12340014

Dunn, C., \& Thomas, D.H. (1997). Rise and demise: Comparing world-systems. Westview.

Dyer, K. (2012). Making 'evidence' the plural of 'anecdote': A work in progress using outcome mapping and the logframe in governance and accountability programming in Tanzania. OM Ideas, 6.

Earl, S., Carden, F., \& Smutylo, T. (2001). Outcome mapping: Building learning and reflection into development programs. International Development Research Centre.

Eisenman, J., \& Stewart, D.T. (2017, January 9). China's New Silk Road is getting muddy. Foreign Policy.

Ellis, C.D. (2017). Indonesia targets maritime in OBOR investment push. Indonesia Briefing. http://www.indonesiabriefing.com/news/indo-nesiatargets-maritime-oborinvestment-push

Ferdinand, P. (2016). Westward ho-The China Dream and 'One Belt, One Road': Chinese foreign policy under $\mathrm{Xi}$ Jinping. International Affairs, 92(4), 941-957. https://doi.org/10.1111/1468-2346.12660

Fernandes, R., \& Pinho, P. (2017). The distinctive nature of spatial development on small islands. Progress in Planning, 112, 1-18. https://doi.org/10.1016/j.progress.2015.08.001

Fettweis, C.J. (2015). On heartlands and chessboards: Classical geopolitics, then and now. Orbis, 59(2), 233-248. https://doi.org/10.1016/j.orbis.2015.02.005

Figueroa, B.L. (2020). Conjuring Puerto Rico's archipelagic, decolonial future. Shima, 14(1), 172-193. https://doi.org/10.21463/shima.14.1.12

Fulton, J. (2016). An analysis of two corridors in China's One Belt One Road Initiative: China-Pakistan and China Central-West Asia. Proceedings of International Conference on Inter-Regional Connectivity: South Asia and Central Asia 2016.

Gamlen, A., Murray, W.E., \& Overton, J. (2017). Investigating education, migration and development: Moving triangles in the Pacific. New Zealand Geographer, 73(1), 3-14. https://doi.org/10.1111/nzg.12146

Gibson, C.C., Andersson, K., Ostrom, E., \& Shivakumar, S. (2005). The Samaritan's dilemma: The political economy of development aid. Oxford University Press.

Graci, S., \& Dodds, R. (2010). Sustainable tourism in island destinations. Earthscan.

Grydehøj, A. (2020). Unravelling economic dependence and independence in relation to island sovereignty: The case of Kalaallit Nunaat (Greenland). Island Studies Journal, 15(1), 89-112. https://doi.org/10.24043/isj.101

Grydehøj, A. (2011). 'It's a funny thing that they were all bad men': Cultural conflict and integrated tourism policy in Shetland, UK. International Journal of Tourism Anthropology, 1(2), 125-140. https://doi.org/10.1504/IJTA.2011.040430

Grydehøj, A., \& Casagrande, M. (2020). Islands of connectivity: Archipelago relationality and transport infrastructure in Venice Lagoon. Area, 52(1), 56-64. https://doi.org/10.1111/area.12529

Grydehøj, A., \& Kelman, I. (2020). Reflections on conspicuous sustainability: Creating Small Island Dependent States (SIDS) through Ostentatious Development Assistance (ODA)?. Geoforum, 116, 90-97. https://doi.org/10.1016/j.geoforum.2020.08.004 
Grydehøj, A., \& Kelman, I. (2017). The eco-island trap: Climate change mitigation and conspicuous sustainability. Area, 49(1), 106-113. https://doi.org/10.1111/area.12300

Grydehøj, A., Nadarajah, Y., \& Markussen, U. (2020). Islands of indigeneity: Cultural distinction, indigenous territory and island spatiality. Area, 52(1), 14-22. https://doi.org/10.1111/area.12520

Hatfield, S.C., \& Hong, S.K. (2019). Mermaids of South Korea: Haenyeo (women divers) traditional ecological knowledge, and climate change impacts. Journal of Marine and Island Cultures, 8(1), 1-16. https://doi.org/10.21463/jmic.2019.08.1.01

Haug, M., \& Rössler, M., \& Grumblies, A.T. (2016). Rethinking power relations in Indonesia: Transforming the margins. Routledge. https://doi.org/10.4324/9781315659190

Haynes, K., Barclay, J., \& Pidgeon, N., (2008). The issue of trust and its influence on risk communication during a volcanic crisis. Bulletin of Volcanology, 70(5), 605-621. https://doi.org/10.1007/s00445-007-0156-z

Hettne, B., \& Söderbaum, F. (1998). The new regionalism approach. Politeia, 17(3), 6-21.

Hillman, J.E. (2018) China's Belt and Road is full of holes. Center for Strategic E International Studies Briefs, September.

Hutchinson, F.E., \& Chong, T. (Eds.). (2016). The SIJORI cross-border region: Transnational politics, economics, and culture. ISEAS-Yusof Ishak Institute. https://doi.org/10.1355/9789814695596

Kakazu, H (2011). Challenges and Opportunities for Japan's Remote Islands. Eurasia Border Review Voices from Asia's "Periphery

Kelman, I. (2020). Islands of vulnerability and resilience: Manufactured stereotypes?. Area, 52(1), 6-13. https://doi.org/10.1111/area.12457

Kelman, I., Lewis, J., Gaillard, J.C., \& Mercer, J. (2011). Participatory action research for dealing with disasters on islands. Island Studies Journal, 6(1), 59-86.

Kelman, I., Burns, T., \& Johansson, M.N. (2015). Islander innovation: A research and action agenda on local responses to global issues. Journal of Marine and Island Cultures, 4, 34-41. https://doi.org/10.1016/j.imic.2015.04.001

King, D., \& Tennant, D.F. (2014). Debt and development in Small Island Developing States. Palgrave MacMillan. https://doi.org/10.1057/9781137392787

Kirch, P.V. (1986). Island societies: Archaeological approaches to evolution and transformation. Cambridge University Press

Kuwahara, S. (2012). The development of small islands in Japan: An historical perspective. Journal of Marine and Island Cultures, 1, 38-45. https://doi.org/10.1016/j.imic.2012.04.004

Lattas, A. (2007). Cargo cults and the politics of alterity: A review article. Anthropological Forum, 17(2), 149-161. https://doi.org/10.1080/00664670701438407

Lee, S.H., Huang, W.H., \& Grydehøj, A (2017). Relational geography of a border island: Local development and compensatory destruction on Lieyu, Taiwan. Island Studies Journal, 12(2), 97-112. https://doi.org/10.24043/isj.33

Lune, H., \& Berg, B.L. (2017). Qualitative research methods for the social sciences. Pearson.

Ma, X., \& Wu, W. (2019). Deficiencies in China's island development processes compared with other countries. Emerging Markets Finance and Trade, 56(13), 2963-2976. https://doi.org/10.1080/1540496X.2019.1644498 
Matsumura, Y., \& Miyoshi, E. (2018). Forces in the development of remote islands in Japan: A case study of local energy enterprises in Tsushima Island. Osaka Human Sciences, 4, 61-83.

Mountz, A. (2011). The enforcement archipelago: Detention, haunting, and asylum on islands. Political

118-128. https://doi.org/10.1016/j.polgeo.2011.01.005

Nurdin, N., \& Grydehøj, A. (2014). Informal governance through patron-client relationships and destructive fishing in Spermonde Archipelago, Indonesia. Journal of Marine and Island Cultures, 3(2), 54-59. https://doi.org/10.1016/j.imic.2014.11.003

Otto, L., Nimführ, S., \& Bieler, P. (2019). Preserving Maltese identity in refugee management: On the emergence and absence of a prison spatiality. Shima, 13(2), 135154. https://doi.org/10.21463/shima.13.2.11

Perucca, G. (2013). The role of territorial capital in local economic growth: Evidence from Italy. European Planning Studies, 22(3), 537562. https://doi.org/10.1080/09654313.2013.771626

Pugalis, L., \& Gray, N. (2016). New regional development paradigms: An exposition of place-based modalities. 22. 181-203.

Pugh, J. (2016). The relational turn in island geographies: Bringing together island, sea and ship relations and the case of the Landship. Social \& Cultural Geography, 17(8), 10401059. https://doi.org/10.1080/14649365.2016.1147064

Putri, H.M., \& Salim, W. (2019) Outer island development in crossborder cooperation framework: Cooperation or exploitation? (Study case: Natuna Island in SingaporeJohor-Riau Cooperation). Proceedings of The 4th International Conference in Planning in the 2019 Era of Uncertainty, Indonesia. https://doi.org/10.1088/1755-1315/328/1/012040

Ratter, B.M.W. (2017) Geography of small islands: Outposts of globalisation. Springer. https://doi.org/10.1007/978-3-319-63869-0 4

Richardson, P.B. (2016). Beyond the nation and into the state: Identity, belonging, and the 'hyper-border'. Transactions of the Institute of British Geographers, 41(2), 201-215. https://doi.org/10.1111/tran.12116

Riska, E. (2017). Diplomasi maritim Indonesia terhadap aktivitas penangkapan ikan illegal (illegal fishing) oleh nelayan China di ZEE Kepulauan Natuna. Jurnal Prodi Diplomasi Pertahanan, 3(2), 33-47.

Royle, S.A. (2001). A geography of islands: Small island insularity. Psychology Press.

Setijadi, C. (2018). Chinese investment and presence in the Riau Islands. Perspective ISEAS, 28.

Siregar (2009). Peran Sosial Ekonomi dan Budaya dalam peningkatan kepedulian Masyarakat Nelayan. Jurnal Sosioteknologi Edisi, 18(8).

Sjarif, S. (2000, September 29). Kerja Sama SIJORI Gagal. Riau Post.

Supriyanto, R.A. (2015). Indonesia's Natuna Islands: The next flashpoint in the South China Sea?. Nanyang Technological University, Singapore, RSIS Commentary, 033.

Turner, J.R., \& Müller, R. (2003). On the nature of the project as a temporary organization. International Journal of Project Management, 21(1), 1-8. https://doi.org/10.1016/S02637863(02)00020-0 
Van der Ploeg, J.D., van Broekhuizen, R., Brunori, G., Sonnino, R., Knickel, K., Tisenkopfs, T., \& Oostindie, H. (2008). Towards a framework for understanding regional rural development. In J.D. van der Ploeg \& T. Marsden (Eds.), Unfolding webs: The dynamics of regional rural development (pp. 1-28). Van Gorcum.

Ventura, F., Brunori, G., Milone, P., \& Berti, G. (2008). The rural web: A synthesis. In J.D. van der Ploeg \& T. Marsden (Eds.), Unfolding webs: The dynamics of regional rural development (pp. 149-174). Van Gorcum.

Weissenbacher, R. (2017). Peripheral integration and disintegration in Europe: The 'European dependency school' revisited. Journal of Contemporary European Studies, 26(1), 81-98. https://doi.org/10.1080/14782804.2017.1302875

Xie, B., Zhu, X., \& Grydehøj, A. (2020). Perceiving the Silk Road Archipelago: Archipelagic relations within the ancient and 21st-Century Maritime Silk Road. Island Studies Journal, 15(2), 55-72. https://doi.org/10.24043/isj.118

Ying, T., \& Zhou, Y. (2007). Community, governments and external capitals in China's rural cultural tourism: A comparative study of two adjacent villages. Tourism Management, 28(1), 96-107. https://doi.org/10.1016/j.tourman.2005.12.025

Zhang, H., \& Grydehøj, A. (2020). Locating the interstitial island: Integration of Zhoushan Archipelago into the Yangtze River Delta urban agglomeration. Urban Studies. Epub ahead of print. https://doi.org/10.1177/0042098020937987

Zhiding, H., \& Dadao, L. (2016). Re-interpretation of the classical geopolitical theories in a critical geopolitical perspective. Journal of Geographical Sciences, 26(12), 1769-1784. https://doi.org/10.1007/s11442-016-1357-1 